\title{
PENGARUH KEPUASAN PELANGGAN TERHADAP LOYALITAS PELANGGAN PADA OBYEK WISATA DUMILAH WATER PARK MADIUN
}

\author{
Widyaninggar Resti Husodho \\ Mahasiswa Prodi Pendidikan Ekonomi IKIP PGRI MADIUN
}

\begin{abstract}
Abstrak. Tujuan dari penelitian ini adalah untuk menentukan kepuasan pelanggan pariwisata Dumilah Water Park Madiun, untuk menentukan loyalitas pelanggan pariwisata Dumilah Water Park Madiun, dan untuk mengukur apakah ada pengaruh kepuasan pelanggan terhadap loyalitas pelanggan di bidang pariwisata Dumilah Water Park Madiun. Populasi dalam penelitian ini adalah 145 pengunjung. Sampel dalam penelitian ini berjumlah 106 pengunjung. Pengambilan sampel menggunakan purposive sampling. Instrumen pengumpulan data menggunakan kuesioner dengan skala Likert yang telah diuji dan memenuhi persyaratan validitas dan reliabilitas. Alat analisis yang digunakan dalam penelitian ini adalah analisis regresi linier sederhana meliputi uji korelasi, uji F dan t-test. Bantuan dalam menganalisis data menggunakan SPSS For Windows versi 16.0. Hasil yang diperoleh dari garis regresi $Y=29.981+0,505 X$, yang berarti bahwa jika ketika kepuasan pelanggan meningkat $1 \%$ maka loyalitas pelanggan akan meningkat $0.505 \%$ ketika faktorfaktor lain yang dianggap tetap. Berdasarkan hasil penelitian diperoleh tingkat nilai $\mathrm{r}_{\text {hitung }}$ 0,495 dan $\mathrm{r}_{\text {tabel }} 0,191$. Berarti bahwa ada hubungan kepuasan pelanggan terhadap loyalitas pelanggan dalam pariwisata Dumilah Water Park Madiun. Sementara, tingkat $\mathrm{R}^{2}$ 0,245. Berarti, pengaruh kontribusi kepuasan pelanggan dengan loyalitas pelanggan 24,5\% sedangkan sisanya 75,5\% dipengaruhi oleh faktor lain. Hal ini juga diperoleh nilai uji $\mathrm{F}$, sedangkan nilai $\mathrm{F}_{\text {hitung }} 33.478$ dan $\mathrm{F}_{\text {tabel }} 3,932\left(\mathrm{~F}_{\text {hitung }} \geq \mathrm{F}_{\text {tabel }} 33.478 \geq 3,932\right)$. Satu sisi lain $\mathrm{Sig}_{\text {hit }}$ 0,000 dan $\operatorname{Sig}_{\text {prob }} 0,05\left(\operatorname{Sig}_{\text {hit }} \leq \operatorname{Sig}_{\text {prob }} 0,000 \leq 0,05\right)$. Berarti ada pengaruh kepuasan pelanggan terhadap loyalitas pelanggan di pariwisata Dumilah Water Park Madiun. Dalam t-test dilakukan menyusul di garis regresi Nilai $\mathrm{t}_{\text {hitung }}$ adalah 22.356 dan $\mathrm{t}_{\text {tabel }} 1.771\left(\mathrm{t}_{\text {hitung }} \geq \mathrm{t}_{\text {tabel }} 22.356\right.$ $\geq 1771)$. Di sisi lain $\operatorname{Sig}_{\text {hit }} 0,000$ dan $\operatorname{Sig}_{\text {prob }} 0,05\left(\operatorname{Sig}_{\text {hit }} \leq \operatorname{Sig}_{\text {prob }} 0,000 \leq 0,05\right)$. Berarti bahwa ada efek yang berbeda dari kepuasan pelanggan terhadap loyalitas pelanggan di bidang pariwisata Dumilah Water Park Madiun. Berdasarkan uji korelasi, Uji F dan uji t dapat disimpulkan bahwa ada pengaruh dari kepuasan pelanggan pada pariwisata loyalitas pelanggan Dumilah Water Park Madiun.
\end{abstract}

Kata Kunci: Kepuasan Pelanggan, Loyalitas Pelanggan

\section{PENDAHULUAN}

Globalisasi membawa dampak yang sangat besar bagi perkembangan dunia bisnis di seluruh dunia. Pasar terbuka luas dan peluang menjadi semakin lebar, namun sebaliknya persaingan menjadi semakin ketat dan sulit diprediksikan. Kondisi ini menuntut setiap perusahaan untuk menciptakan keunggulan kompetitif bisnisnya agar mampu bersaing secara berkesinambungan dengan perusahaan-perusahaan lain yang berkecimpung dalam bidang yang sama. Perusahaan yang ingin berkembang dan mendapatkan keunggulan kompetitif harus dapat memberikan produk berupa barang atau jasa yang berkualitas dan pelayanan yang baik kepada 
para pelanggan, sehingga akan muncul kepuasan dalam benak pelanggan dan diharapkan akan membawa dampak positif bagi perusahaan.

Perusahaan rekreasi sebagai perusahaan yang bergerak dalam bidang jasa dituntut untuk mengerti kebutuhan konsumen untuk kemudian menyesuaikan kemampuan perusahaan dengan kebutuhan dan keinginan konsumen. Hal ini diperlukan karena jasa mempunyai sifat yang berbeda dengan barang.

Fandy Tjiptono (2007:18-23) menyatakan bahwa jasa mempunyai sifat Intangibility, jasa tidak dapat dilihat, dirasa, dicium, didengar, atau diraba sebelum dibeli dan dikonsumsi. Inseparability, jasa pada umumnya dijual terlebih dahulu, baru kemudian diproduksi dan dikonsumsi pada waktu dan tempat yang sama.

Variability/heterogenity/inconsistency, banyak variasi bentuk, kualitas, dan jenis, tergantung kepada siapa, kapan, dan di mana jasa tersebut di produksi. Perishability, jasa tidak tahan lama dan tidak dapat disimpan. Lack of ownership, jasa tidak tahan lama dan tidak dapat disimpan.

Dalam lingkungan yang terus berkembang dan cepat berubah faktor kunci keberhasilan untuk bertahan hidup di pasar bergantung pada mempertahankan hubungan jangka panjang antara pemasok dan pembeli. Tantangan yang semua pemasar sedang hadapi saat ini adalah menemukan cara meningkatkan kepuasan pelanggan.

Menurut Zulian Yamit (2010:78), bahwa kepuasan pelanggan adalah hasil (outcome) yang dirasakan atas penggunaan produk dan jasa atau melebihi harapan yang dinginkan.

Sedangkan menurut Day (1998) dalam Nasution (2004:104) menyatakan bahwa kepuasan atau ketidakpuasan pelanggan adalah respon pelanggan terhadap evaluasai ketidaksesuaian/diskormasi yang dirasakan antara harapan sebelumnya (atau norma kinerja lainnya) dan kinerja actual produk yang dirasakan setelah pemakaiannya.

Menurut Rambat Lupiyoadi (2001:158) di dalam menentukan tingkat kepuasan pelanggan ada lima faktor utama, yaitu :

1) Kualitas Produk

Pelanggan akan merasa puas jika hasil evaluasi mereka menunjukkan bahwa produk yang mereka gunakan berkualitas.

2) Kualitas Pelayanan

Pelanggan akan merasa puas jika mereka mendapatkan pelayanan yang baik atau sesuai dengan yang diharapkan.

3) Emosional

Pelanggan akan merasa bangga dan mendapatkan keyakinan bahwa orang lain akan kagum terhadap dia jika menggunakan produk dengan merek tertentu yang cenderung mempunyai tingkat kepuasan yang lebih tinggi (Nilai sosial).

4) Harga

Produk yang mempunyai kualitas yang sama namun memberikan harga yang lebih murah, akan memberikan nilai yang lebih tinggi kepada pelanggannya.

5) Biaya

Pelanggan yang tidak perlu mengeluarkan biaya tambahan atau tidak perlu membuang waktu untuk mendapatkan suatu produk atau jasa cenderung puas terhadap suatu produk atau jasa itu.

Banyak perusahaan yang tidak dapat mencapai sasaran penjualan, hal ini sering dikarenakan oleh kurang tepatnya perusahaan dalam memberikan strategi kepuasan pelanggan, sehingga kesetiaan pelanggan terhadap barang atau jasa yang ditawarkan perusahaan sulit untuk dipertahankan. Untuk mempertahankan pelanggan yang sudah ada, 
pihak perusahaan atau pengusaha dituntut untuk selalu tanggap terhadap apa yang diinginkan pelanggan.

Menurut Fandy (2000) dalam Nasution (2004:112-113) dalam hal terjadi ketidakpuasan, ada beberapa kemungkinan tindakan yang bisa dilakukan pelanggan yaitu tidak melakukan apa-apa dan melakukan komplain.

Dari kemungkinan ketidakpuasan di atas dapat dijelaskan sebagai berikut:

1) Tidak melakukan apa-apa

Pelanggan yang tidak puas praktis tidak akan membeli atau menggunakan jasa perusahaan yang bersangkutan lagi.

2) Melakukan komplain

Ada beberapa faktor yang mempengaruhi apakah seorang pelanggan yang tidak puas akan melakukan complain atau tidak, yaitu sebagai berikut:

a) Derajat kepentingan konsumsi yang dilakukan

Hal ini menyangkut derajat kepentingan jasa yang dikonsumsi dengan harganya bagi konsumen, waktu yang dibutuhkan untuk mengkonsumsi jasa serta visibility.

b) Tingkat ketidakpuasan pelanggan Makin puas seorang pelanggan, maka makin besar kemungkinan ia melakukan komplain.

c) Manfaat yang diperoleh

Manfaat yang dapat diperoleh terdiri dari empat jenis, yaitu :

(1) Manfaat emosional, yakni kesempatan untut menuntut hak menumpahkan kekesalan dan kemarahan serta menerima permintaan maaf.

(2) Manfaat fungsional, yakni pengambilan uang penggantian jasa yang dibeli reparasi dan lain-lain.

(3) Manfaat bagi orang lain, yakni membantu pelanggan lain agar terhindar dari ketidakpuasan akibat pelayanan yang buruk.

(4) Penyempurnaan jasa, yakni perusahaan jasa kemungkinan besar akan meningkatkan atau memperbaiki penawarannya.

d) Pengetahuan dan pengalaman

Hal ini meliputi jumlah pembelian (pemakaian jasa) sebelumnya, pemahaman akan jasa.

e) Sikap pelanggan terhadap keluhan Pelanggan yang bersifat positif terhadap penyampaian keluhan biasanya sering menyampaikan keluhan, yakni karena ada manfaat positif yang akan diterimanya.

f) Tingkat kesulitan dalam mendapatkan ganti rugi

Faktor ini mencakup waktu yang dibutuhkan, gangguan terhadap aktivitas rutin yang dijalankan, dan biaya yang dibutuhkan untuk melakukan komplain.

g) Peluang keberhasilan dalam melakukan kompain

Bila pelanggan merasa bahwa peluang keberhasilannya dalam melakukan komplain sangat kecil, maka ia cenderung tidak akan melakukannya. Hal ini sebaliknya, apabila dirasakan peluangnya besar.

Menurut Nasution (2004:127-133) ada beberapa strategi yang dapat dipadukan untuk meraih dan meningkatkan kepuasan pelanggan, di antaranya :

\section{1) Relationship Marketing}

Dalam hal ini, hubungan transaksi antara penyedia jasa dan pelanggan berkelanjutan, tidak berakhir walaupun penjualan sudah selesai. Dengan kata lain, dijalin suatu kemitraan jangka panjang dengan 
pelanggan secara terus-menerus sehingga diharapkan dapat terjadi bisnis ulangan (repeatbusiness).

\section{2) Superior Customer Service}

Untuk dapat meningkatkan kepuasan pelanggan, perusahaan jasa dapat mengembangkan augmented service terhadap core servis-nya, misalnya dengan merancang garansi tertentu atau dengan memberikan pelayanan penjualan yang baik. Pelayanan purnajual ini harus pula menyediakan media yang efisien dan efektif untuk menangani keluhan.

3) Unconditional Guarantees/Extraordinary

\section{Guarantees}

Strategi unconditional guarantees berintikan komitmen untuk memberikan kepuasan kepada pelanggan, yang pada gilirannya akan menjadi sumber dinamis penyempurnaan kualitas jasa dan kinerja perusahaan.

4) Penanganan keluhan pelanggan

Penanganan keluhan yang baik memberikan peluang untuk mengubah seorang pelanggan yang tidak puas menjadi pelanggan yang puas (atau bahkan pelanggan 'abadi').

Setelah perusahaan menjaga kepuasan pelanggan, maka perusahaan akan mendapat banyak sekali manfaat yang akan diterima dari kepuasan yang dirasakan oleh pelanggan.

Menurut Fandy Tjiptono (2007:352354) manfaat dari program kepuasan di antaranya sebagai berikut:

1) Reaksi terhadap produsen berbiaya rendah Persaingan dalam banyak industri ditandai dengan overcapacity dan oversupply. Dalam berbagai kasus, hal ini menyebabkan pemotongan harga menjadi senjata strategis untuk meraih pangsa pasar. Fokus pada kepuasan pelanggan merupakan upaya mempertahankan pelanggan dalam rangka menghadapi para produsen berbiaya rendah.

2) Manfaat ekonomis retensi pelanggan versus perpetual prospecting

Berbagai studi menunjukkan bahwa mempertahankan dan memuaskan pelanggan saat ini jauh lebih murah daripada terusmenerus berupaya menarik atau memprospek pelanggan baru.

3) Nilai kumulatif dari relasi berkelanjutan Berdasarkan konsep "customer lifetime value”, upaya mempertahankan loyalitas pelanggan terhadap produk atau jasa perusahaan selama periode waktu yang lama bisa menghasilkan anuitas yang jauh lebih besar dari pada pembelian individual.

4) Daya persuasive ghetok tular (word of mouth)

Dalam industri (terutama sektor jasa), pendapat/opini dari teman dan keluarga jauh lebih persuasive dan kredibel dari pada iklan. Oleh sebab itu, banyak perusahaan yang tidak hanya meneliti kepuasan total, namun juga menelaah sejauh mana pelanggan bersedia merekomendasikan produk perusahaan kepada orang lain.

5) Reduksi sensitive harga

Pelanggan yang puas dan loyal terhadap sebuah perusahaan cenderung lebih jarang menawar harga untuk setiap pembelian individualnya. Hal itu disebabkan faktor kepercayaan telah terbentuk.

6) Kepuasan pelanggan sebagai indikator kesuksesan bisnis di masa depan

Pada hakikatnya kepuasan pelanggan merupakan strategi jangka panjang, karena dibutuhkan waktu cukup lama sebelum bisa membangun dan mendapatkan reputasi atas layanan prima.

Selain kepuasan pelanggan kunci 
keunggulan bersaing dalam situasi yang penuh persaingan adalah kemampuan perusahaan dalam meningkatkan loyalitas pelanggan. Kesetiaan pelanggan akan menjadi kunci sukses dan keunggulan bersaing perusahaan tidak hanya dalam jangka pendek juga dalam jangka panjang.

Persaingan yang ada dalam dunia bisnis mendorong perusahaan untuk menciptakan pemikiran-pemikiran baru mengenai cara mempertahankan dan mendapatkan pelanggan baru. Dengan kondisi persaingan yang semakin ketat antar perusahaan sejenis, setiap perusahaan harus mampu berlomba untuk memperluas pasarnya.

Loyalitas Pelanggan merupakan hal yang terpenting dalam kegiatan suatu usaha. Menurut Menurut Sheth \& Mittal (2004) dalam Fandy Tjiptono (2007: 387) "loyalitas pelanggan adalah komitmen pelanggan terhadap suatu merek, toko atau pemasok, berdasarkan sikap yang sangat positif dan tercermin dalam pembelian ulang yang konsisten".

Menurut Swastha (2009) dalam Nurullaili dan Andi Wijayanto (2013:91) definisi loyalitas pelanggan adalah kesetiaan konsumen untuk terus menggunakan produk yang sama dari suatu perusahaan. Loyalitas menggambarkan perilaku yang diharapkan sehubungan dengan produk atau jasa. Loyalitas konsumen akan tinggi apabila suatu produk dinilai mampu memberi kepuasan tertinggi sehingga pelanggan enggan untuk beralih ke merek lain.

Dengan adanya tingkat loyalitas konsumen yang tinggi, maka konsumen akan melakukan pembelian secara terus - menerus dan membawa dampak yang menguntungkan bagi perusahaan.

Menurut Schiffman dan Kanuk (2004) dalam Faisal Matriadi, Teuku Edyansyah, dan Syafuddin (2013: 86-87) faktor-faktor yang mempengaruhi loyalitas pelanggan adalah:
1) Penerimaan Keunggulan Produk (Perceived Product Superiority)

Pelanggan menerima dengan baik setiap keunggulan produk yang ditawarkan oleh perusahaan dalam kaitan untuk terciptanya loyalitas terhadap produk yang ditawarkan tersebut.

2) Keyakinan yang dimiliki seseorang terhadap Merek (Personal Fortitude)

Perusahaan selaku produsen produk harus berusaha untuk menciptakan keyakinan pelanggan terhadap merek, karena tanpa adanya keyakinan terhadap merek maka pelanggan sulit untuk melakukan pembelian terhadap merek dimaksud.

3) Keterikatan dengan Produk atau Perusahaan (Bonding with the Product or Company)

Keterkaitan pelanggan dengan produk harus diciptakan oleh perusahaan karena untuk membangun hubungan dengan pelanggan sehingga pelanggan akan tetap berlangganan terhadap produk perusahaan.

4) Kepuasan yang diperoleh Pelanggan (Customer Satisfaction)

Salah satu hal yang penting untuk dirancang oleh perusahaan adalah menciptakan kepuasan pelanggan. Pelanggan yang puas tercipta karena produk yang dikonsumsi memenuhi harapan pelanggan. Dengan pelanggan yang merasa puas maka akan mengurangi keluhan dalam menggunakan produk. Kepuasan pelanggan tersebut pada akhirnya juga akan menjadikan loyalitas pelanggan.

Menurut Fandy Tjiptono (2007:410411) upaya mewujudkan dan mempertahankan loyalitas pelanggan ada beberapa cara yaitu:

1) Komitmen dan keterlibatan manajemen puncak 
Komitmen dan keterlibatan manajer puncak sangatlah mempunyai peran penting dalam menciptakan loyalitas pelanggan. Dukungan, manajer puncak selalu dibutuhkan dalam rangka melakukan transformasi budaya organisasi, struktur kerja, dan praktik manajemen sumber daya manusia dari paradigma tradisional menuju paradigma pelanggan.

Untuk memfasilitasi proses transformasi tersebut, manajer puncak harus melakukan beberapa hal, yakni:

a) Memahami secara sungguh-sungguh potensi loyalitas dan retensi pelanggan.

b) Membentuk steering committee loyalitas pelanggan yang dipimpin seorang CCO (ChiefCustomer Officer).

c) Menetapkan sasaran spesifik dan kuantitatif mengenai customer defectation rate.

d) Bersama-sama streering committee tersebut merumuskan pernyataan misi retensi pelanggan.

e) Menguantifikasi lifetime value pelanggan dan lifetime loss dari setiap defecting customer.

f) Mempraktikkan defections management, mulai dari antisipasi dan analisis setiap kemungkinan customer defecting sampai membujuk mereka untuk kembali menjadi pelanggan perusahaan.

2) Patok duga internal (Internal Benchmarking)

Patok duga internal merupakan pengukuran dan penilaian atas manajemen, sumber daya manusia, organisasi, sistem, alat, desain, pemasok, pemanufaktur, pemasaran, dan jasa pendukung perushaan yang dapat mempertahankan pelanggan.

3) Mengidentifikasi Customer requirements Identifikasi Customer requirements dapat dilakukan dengan menggunakan beberapa metode mutakhir seperti value research, customer window model, analisis sensitivitas, evaluasi multiatribut, analisis conjoin, dan QFD (Quality Function Deployment).

4) Menilai kapasitas persaingan

Untuk menilai kapasitas persaingan (terutama yang terkuat) harus diidentifikasi secara cermat.

5) Mengukur kepuasan dan loyalitas pelanggan

Kepuasan pelanggan menyangkut apa yang diungkapkan oleh pelanggan, sedang loyalitas pelanggan berkaitan dengan apa yang dilakukan pelanggan. Data kepuasan dan loyalitas diperoleh dari umpan balik pelanggan yang bisa dikumpulkan melalui berbagai cara tingkat efektivitasnya bervariasi, misalnya observasi aktif dan pasif, kartu dan kotak saran, saluran telepon bebas pulsa, survey.

6) Menganalisis umpan balik dari pelanggan, mantan pelanggan, non-pelanggan, dan pesaing.

Dengan menganalisis pelanggan atau non pelanggan dan pesaing, perusahaan bisa memahami secara lebih baik faktor-faktor yang menunjang kepuasan dan loyalitas pelanggan, serta faktor negative yang berpotensi menimbulkan customer defections.

7) Perbaikan berkesinambungan

Perusahaan harus selalu aktif mencari berbagai inovasi dan terobosan dalam merespon setiap perubahan yang sangat bermanfaat dalam membantu proses perbaikan organisasi perusahaan.

Fornell (1992) dalam Danang Sunyoto (2013:193) menyebutkan bahwa tingkat kepuasan yang tinggi dapat meningkatkan loyalitas pelanggan dan mencegah perputaran 
pelanggan, mengurangi sensitivitas pelanggan terhadap harga, mengurangi biaya kegagalan pemasaran, mengurangi biaya operasi yang diakibatkan oleh meningkatnya jumlah pelanggan, meningkatkan efektivitas iklim dan meningkatkan reputasi bisnis.

Selain itu menurut Jones dan Sasser (1994 : 745) dalam Rina Rachmawati (2010 : 75-76) menyatakan bahwa loyalitas pelanggan merupakan suatu variabel endogen yang disebabkan oleh kombinasi dari kepuasan sehingga loyalitas pelanggan merupakan fungsi dari kepuasan. Jika hubungan antara kepuasan dengan loyalitas pelanggan adalah positif, maka kepuasan yang tinggi akan meningkatkan loyalitas pelanggan. Dalam hal ini loyalitas pelanggan berfungsi sebagai $\mathrm{Y}$ sedangkan kepuasan pelanggan berfungsi sebagai $\mathrm{X}$.

\section{METODELOGI PENELITIAN}

Penelitian dilaksanakan di Dumilah Water Park Madiun di Jalan Slamet Riyadi No.99. Desain yang digunakan adalah metode penelitian deskriptif. Menurut Punaji Setyosari (2010: 33-34) penelitian deskriptif merupakan penelitian yang bertujuan untuk menjelaskan atau mendeskripsikan suatu keadaan, peristiwa, objek apakah orang, atau segala sesuatu yang terkait dengan variabelvariabel yang bisa dijelaskan baik dengan angka-angka maupun kata-kata.

Dengan penelitian deskriptif, peneliti menggunakan stategi kuantitatif (misalnya, teknik kuesioner dan observasi) untuk mengumpulkan data (misalnya, berupa skor) atau informasi tentang ciri-ciri orang, kelompok orang, program, atau sesuatu yang berkaitan dengan pendidikan.

\section{Variabel Penelitian}

Dalam penelitian ini yang menjadi variabel bebas (X) adalah kepuasan pelanggan dan variabel terikat (Y) adalah loyalitas pelanggan.

1. Kepuasan Pelanggan

Menurut Sugiyono (2012:4) variabel bebas adalah variabel yang mempengaruhi atau yang menjadi sebab perubahan atau timbulnya variabel dependen (terikat).

Menurut Thamrin dan Francis (2012:38) kepuasan adalah tingkat perasaan seseorang setelah membandingkan kinerja produk (atau hasil) yang ia rasakan dengan harapannya.

2. Definisi loyalitas

Menurut Sugiyono (2012:4) variabel terikat adalah variabel yang dipengaruhi atau yang menjadi akibat, karena adanya variabel bebas.

Menurut Bendaputi \& Berry (1997) dalam Fandy Tjiptono (2007:387) "loyalitas pelanggan didefinisikan sebagai respon yang terikat erat dengan ikrar atau janji untuk memegang teguh komitmen yang mendasari kontinuitas relasi, dan biasanya tercermin dalam pembelian berkelanjutan dari penyedia jasa yang sama atas dasar dedikasi maupun kendala pragmatis".

\section{Populasi, Sampel, Teknik Pengambilan Sampel}

Populasi dalam penelitian ini adalah 145 pengunjung Dumilah Water Park Madiun. Sampel dalam penelitian ini sebanyak 106 pengunjung. Teknik pengambilan sampel menggunakan Simple Random Sampling yaitu pengambilan sampel dilakukan secara acak tanpa memperhatikan strata yang ada dalam populasi itu.

Perhitungan jumlah sampel dengan rumus dari Taro Yamane dalam I Made Suska, N. Budiartha R.M, Gd. Astawa Dipura (2013: 39) yaitu: 


$$
n=\frac{N}{N \cdot d^{2}+1}
$$

Dimana :

$\mathrm{n}=$ ukuran sampel

$\mathrm{N}=$ ukuran populasi

$\mathrm{d}=$ batas ketelitian (dalam \%)

Berdasarkan rumus tersebut maka penentuan jumlah sampel dalam penelitian ini sebagai berikut:

$$
n=\frac{N}{N \cdot d^{2}+1}
$$$$
n=\frac{145}{145 \cdot(0,05)^{2}+1}
$$

$n=\frac{145}{1,3625}$

$n=106,42$

( dibulatkan menjadi 106)

Jadi sampel dalam penelitian ini adalah 106 pengunjung.

Data dalam penelitian ini dikumpulkan dengan menggunakan teknik:

\section{Kuesioner}

Dalam penelitian ini kuesioner berupa pertanyaan-pertanyaan yang akan diberikan kepada responden untuk mengetahui kepuasan pelanggan terhadap loyalitas pelanggan pada Obyek Wisata Dumilah Water Park Madiun. Jumlah soal dalam angket adalah 30 soal terdiri dari 15 soal untuk variabel kepuasan pelanggan dan 15 soal untuk loyalitas pelanggan.

\section{Observasi}

Dalam penelitian ini pengumpulan data dilakukan dengan cara peninjauan secara langsung ke obyek penelitian yaitu Obyek Wisata Dumilah Park Madiun untuk memperoleh data yang diperlukan untuk kelancaran penyusunan penelitian yang berkaitan.

\section{Wawancara}

Dalam penelitian ini wawancara yang akan dilakukan yaitu dengan mewawancarai pihak-pihak yang bersangkutan untuk memperoleh data yang berhubungan dengan materi pembahasan dalam penyusunan penelitian yaitu untuk mengetahui sejarah, struktur organisasi dan fasilitas yang ada di Dumilah Water Park Madiun.

Analisis data dalam penelitian ini peneliti menggunakan Analisis Regresi Linier dengan perhitungan Uji SPSS (Statistical Product and Service Solutions) for Windows versi 16.0. Untuk pengujian instrumen dalam penelitian ini digunakan uji validitas. Validitas yang digunakan dalam penelitian ini menggambarkan kesesuaian sebuah pengukur data dengan apa yang akan diukur. Pengambilan keputusan berdasarkan nilai $\mathrm{p}$ value/nilai signifikasi kurang dari 0,05 (5\%) maka item pertanyaan tersebut dinyatakan valid dan sebaliknya jika nilai $\mathrm{p}$ value atau signifikasi sama dengan atau lebih dari 0,05 (5\%) dinilai tidak valid.

Dalam penelitian ini uji reliabilitas terhadap instrument menggunakan uji Cronbach Alpha. Bila nilai alpha lebih besar dari 0,6 menunjukkan bahwa data telah reliabel Imam Ghozali (2003) dalam Faizal M., Teuku E. dan Saifudin (2013:88).

Analisis data yang digunakan untuk mencari pengaruh antara kepuasan pelanggan dan loyalitas pelanggan digunakan analisis regresi linier sederhana yang terdiri dari uji korelasi, uji Fisher dan uji t.

\section{HASIL PENELITIAN}

\section{Variabel kepuasan pelanggan}

Deskriptif dari variabel kepuasan pelanggan (X) dengan jumlah $(\mathrm{N})$ sebanyak 106 orang mempunyai deskriptif data sebagai berikut: (a) nilai rata-rata 64,77; (b) nilai 
tengah 65,00; (c) angka yang sering muncul 63; (d) standar deviasi 3,994; (e) nilai minimum 54; (f) nilai maksimum 71; (g) jumlah 6866.

\section{Variabel loyalitas pelanggan}

Deskriptif dari variabel loyalitas pelanggan (Y) dengan jumlah (N) 106 orang mempunyai deskriptif data sebagai berikut: (a) nilai rata-rata 62,66; (b) nilai tengah 63,50; (c) angka yang sering muncul 64; (d) standar deviasi 4,071; (e) nilai minimum 52; (f) nilai maksimum 75; (g) jumlah 6642.

\section{Hasil Uji Prasarat}

Hasil Uji Validitas dengan perhitungan Korelasi Product Moment menunjukkan bahwa semua item soal dalam angket tersebut valid. Semua item soal dinyatakan valid karena semua nilai korelasi atau $r$ hitung untuk masing-masing butir pernyataan variabel bebas kepuasan pelanggan mempunyai nilai $\mathrm{r}$ hitung $>\mathrm{r}$ tabel 0,189 berarti semua butir pernyataan tidak ada yang dibuang. Dengan kata lain semua pernyataan valid dan dapat dipergunakan oleh peneliti sebagai instrument penelitian. Sedangkan Hasil Validitas untuk variabel loyalitas pelanggan mempunyai nilai nilai $r$ hitung $>r$ tabel 0,189 berarti semua butir pernyataan tidak ada yang dibuang. Dengan kata lain semua pernyataan valid dan dapat dipergunakan oleh peneliti sebagai instrument penelitian.

Hasil Uji Reliabilitas terhadap angket kepuasan pelanggan mempunyai nilai Cronbach Alpha 0,733. a 0,733>0,60 maka dapat disimpulkan bahwa semua instrument yang digunakan dalam mengukur variabel adalah reliabel. Sedangkan Hasil Uji Reliabilitas terhadap angket loyalitas pelanggan mempunyai nilai Cronbach Alpha 0,694. $\alpha$ 0,694 >0,60 maka dapat disimpulkan bahwa semua instrument yang digunakan dalam mengukur variabel adalah reliabel.

\section{Hasil Uji Hipotesis}

\section{Hasil Analisis Regresi Linier Sederhana}

Hasil penelitian diperoleh garis regresi $\mathrm{Y}=29,981+0,505 \mathrm{X}$. Artinya apabila kepuasan pelanggan ditingkatkan $1 \%$ maka loyalitas pelanggan akan naik 0,505\%, apabila faktor lain dianggap tetap.

\section{Hasil Uji Korelasi}

Uji Korelasi dilakukan untuk mengetahui hubungan antara kepuasan pelanggan terhadap loyalitas pelanggan.

Hasil uji korelasi didapat besarnya nilai $\mathrm{r}_{\text {hitung }}$ adalah 0,495 sedangkan $\mathrm{r}_{\text {tabel }} 0,191$. Hal ini berarti bahwa nilai $r_{\text {hitung }} \geq r_{\text {tabel }}(0,495 \geq$ 0,191). Atas dasar uji korelasi tersebut dapat disimpulkan tolak $\mathrm{H}_{0}$, artinya ada hubungan kepuasan pelanggan terhadap loyalitas pelanggan pada Obyek Wisata Dumilah Water Park Madiun.

Di lain pihak dalam uji determinasi yang diperoleh nilai $\mathrm{R}^{2}$ ( $\mathrm{R}$ Square) atau koefisien determinasi yang digunakan untuk mengetahui seberapa besar prosentase sumbangan kepuasan pelanggan terhadap loyalitas pelanggan. Berdasarkan hasil analisis di atas dapat diketahui nilai $\mathrm{R}^{2}$ adalah 0,245 . Jadi sumbangan pengaruh dari kepuasan pelanggan terhadap loyalitas pelanggan yaitu $24,5 \%$ sedangkan sisanya sebesar 75,5\% dipengaruhi oleh faktor lain.

\section{Hasil Uji Fisher}

Uji Fisher dilakukan untuk mengetahui pengaruh antara kepuasan pelanggan terhadap loyalitas pelanggan.

Dari uji Fisher diperolah besarnya nilai $F_{\text {hitung }}$ adalah 33,748 sedangkan $F_{\text {tabel }}$ sebesar 
3,932, di lain pihak besarnya $\operatorname{Sig}_{\text {hit }}$ adalah 0,000 sedangkan $\mathrm{Sig}_{\text {prob }}$ 0,05. Hal ini berarti bahwa nilai $F_{\text {hitung }} \geq F_{\text {tabel }}(33,748 \geq 3,932)$ atau $\operatorname{Sig}_{\text {hit }} \leq \operatorname{Sig}_{\text {prob }}(0,000 \leq 0,05)$. Atas dasar uji Fisher tersebut dapat disimpulkan tolak $\mathrm{H}_{0}$, artinya ada pengaruh kepuasan pelanggan terhadap loyalitas pelanggan Obyek Wisata Dumilah Water Park Madiun.

\section{Hasil Uji t}

Uji t digunakan untuk mencari beda pengaruh antara kepuasan pelanggan terhadap loyalitas pelanggan.

Hasil dari analisis uji $t$ dapat diketahui bahwa nilai $t_{\text {hitung }}$ adalah 5,809 sedangkan $t_{\text {tabel }}$ sebesar 1,660, di lain pihak nilai Sig $_{\text {hit }}$ adalah 0,000 sedangkan $\operatorname{Sig}_{\text {prob }}$ 0,05. Hal ini berarti bahwa nilai $t_{\text {hitung }} \geq t_{\text {tabel }}(5,809 \geq 1,660)$ atau $\operatorname{Sig}_{\text {hit }} \leq \operatorname{Sig}_{\text {prob }}(0,000 \leq 0,05)$. Atas dasar uji t tersebut dapat disimpulkan tolak $\mathrm{H}_{0}$, artinya ada beda pengaruh kepuasan pelanggan terhadap loyalitas pelanggan pada Obyek Wisata Dumilah Water Park Madiun.

\section{Simpulan Hasil Analisis}

Dari hasil analisis di atas yang telah dilakukan dapat diambil simpulan sebagai berikut.

\section{Simpulan Analisis Regresi Linier Seder- hana}

Hasil penelitian diperoleh garis regresi $\mathrm{Y}=29,981+0,505 \mathrm{X}$. Artinya apabila kepuasan pelanggan ditingkatkan $1 \%$ maka loyalitas pelanggan akan naik 0,505\%, apabila faktor lain dianggap tetap.

\section{Simpulan Uji Korelasi}

Hasil uji korelasi didapat besarnya nilai $r_{\text {hitung }}$ adalah 0,495 sedangkan $r_{\text {tabel }} 0,191$. Hal ini berarti bahwa nilai $r_{\text {hitung }} \geq r_{\text {tabel }}(0,495 \geq$
0,191). Atas dasar uji korelasi tersebut dapat disimpulkan tolak $\mathrm{H}_{0}$, artinya ada hubungan kepuasan pelanggan terhadap loyalitas pelanggan pada Obyek Wisata Dumilah Water Park Madiun. Selain itu diperoleh $\mathrm{R}^{2}$ adalah 0,245. Jadi sumbangan pengaruh dari kepuasan pelanggan terhadap loyalitas pelanggan yaitu 24,5\% sedangkan sisanya sebesar 75,5\% dipengaruhi oleh faktor lain.

Sesuai hipotesis yang diajukan dapat diperoleh simpulan bahwa ada hubungan kepuasan pelanggan terhadap loyalitas pelanggan pada Obyek Wisata Dumilah Water Park Madiun.

\section{Simpulan Uji Fisher}

Dari uji Fisher diperoleh besarnya nilai $\mathrm{F}_{\text {hitung }}$ adalah 33,748 sedangkan $\mathrm{F}_{\text {tabel }}$ sebesar 3,932, di lain pihak besarnya $\mathrm{Sig}_{\text {hit }}$ adalah 0,000 sedangkan $\mathrm{Sig}_{\text {prob }}$ 0,05. Hal ini berarti bahwa nilai $F_{\text {hitung }} \geq F_{\text {tabel }}(33,748 \geq 3,932)$ atau $\operatorname{Sig}_{\text {hit }} \leq \operatorname{Sig}_{\text {prob }}(0,000 \leq 0,05)$.

Sesuai hipotesis yang diajukan dapat diperoleh simpulan bahwa ada pengaruh kepuasan pelanggan terhadap loyalitas pelanggan Obyek Wisata Dumilah Water Park Madiun.

\section{Simpulan Uji t}

Dari analisis uji t diketahui bahwa nilai $\mathrm{t}_{\text {hitung }}$ adalah 5,809 sedangkan $\mathrm{t}_{\text {tabel }}$ sebesar 1,660, di lain pihak nilai $\mathrm{Sig}_{\text {hit }}$ adalah 0,000 sedangkan $\mathrm{Sig}_{\text {prob }}$ 0,05. Hal ini berarti bahwa nilai $\mathrm{t}_{\text {hitung }} \geq \mathrm{t}_{\text {tabel }}(5,809 \geq 1,660)$ atau $\operatorname{Sig}_{\text {hit }} \leq$ $\operatorname{Sig}_{\text {prob }}(0,000 \leq 0,05)$.

Sesuai hipotesis yang diajukan dapat diperoleh simpulan bahwa ada beda pengaruh kepuasan pelanggan terhadap loyalitas pelanggan pada Obyek Wisata Dumilah Water Park Madiun. 


\section{PEMBAHASAN}

Dari hasil penelitian diperoleh persamaan garis regresi $\mathrm{Y}=29,981+0,505 \mathrm{X}$. Artinya apabila kepuasan pelanggan ditingkatkan 1\% maka loyalitas pelanggan akan naik $0,505 \%$, apabila faktor lain dianggap tetap.

Dalam penelitian ini didapat nilai koefisien determinasi sebesar 0,245 (24,5\%) sedangkan sisanya dipengaruhi oleh faktor lain sebesar 75,5\%.

Nilai Adjusted $\mathrm{R}^{2}$ yang ditunjukkan dalam analisis hasil penelitian ini membuktikan bahwa kepuasan pelanggan mempengaruhi loyalitas pelanggan.

Selanjutnya adalah pembahasan untuk uji regresi (uji korelasi, uji Fisher, dan uji t):

\section{Pembahasan Uji Korelasi}

Berdasarkan hasil analisis di atas diketahui bahwa besarnya nilai $r_{\text {hitung }}$ adalah 0,495 sedangkan $r_{\text {tabel }} 0,191$. Hal ini berarti bahwa nilai $r_{\text {hitung }} \geq r_{\text {tabel }}(0,495 \geq 0,191)$. Atas dasar uji korelasi tersebut dapat disimpulkan tolak $\mathrm{H}_{0}$, artinya ada hubungan kepuasan pelanggan terhadap loyalitas pelanggan pada Obyek Wisata Dumilah Water Park Madiun.

\section{Pembahasan Uji Fisher}

Hasil dari pengujian Fisher dengan ANOVA dapat diperoleh nilai $F_{\text {hitung }}$ adalah 33,748 sedangkan $\mathrm{F}_{\text {tabel }}$ sebesar 3,932, di lain pihak besarnya $\mathrm{Sig}_{\text {hit }}$ adalah 0,000 sedangkan $\operatorname{Sig}_{\text {prob }} 0,05$. Hal ini berarti bahwa nilai $\mathrm{F}_{\text {hitung }} \geq$ $\mathrm{F}_{\text {tabel }}(33,748 \geq 3,932)$ atau $\mathrm{Sig}_{\text {hit }} \leq \operatorname{Sig}_{\text {prob }}$ $(0,000 \leq 0,05)$. Atas dasar uji Fisher tersebut dapat disimpulkan tolak $\mathrm{H}_{0}$, artinya ada pengaruh kepuasan pelanggan terhadap loyalitas pelanggan pada Obyek Wisata Dumilah Water Park Madiun.

\section{Pembahasan Ujit}

Untuk uji $t$ diketahui bahwa nilai $t_{\text {hitung }}$ adalah 5,809 sedangkan $t_{\text {tabel }}$ sebesar 1,660, di lain pihak nilai $\mathrm{Sig}_{\text {hit }}$ adalah 0,000 sedangkan $\operatorname{Sig}_{\text {prob }} 0,05$. Hal ini berarti bahwa nilai $\mathrm{t}_{\text {hitung }} \geq$ $\mathrm{t}_{\text {tabel }}(5,809 \geq 1,660)$ atau $\operatorname{Sig}_{\text {hit }} \leq \operatorname{Sig}_{\text {prob }}(0,000$ $\leq 0,05)$. Atas dasar uji $t$ tersebut dapat disimpulkan tolak $\mathrm{H}_{0}$, artinya ada beda pengaruh kepuasan pelanggan terhadap loyalitas pelanggan pada Obyek Wisata Dumilah Water Park Madiun.

Menciptakan kepuasan pelanggan merupakan tujuan dari perusahaan. Pada dasarnya pelanggan hanya menginginkan kepuasan dari apa yang mereka dapatkan. Pelanggan akan merasa puas jika barang atau jasa yang mereka dapatkan mampu memenuhi harapannya. Hal ini diperkuat oleh Thamrin dan Francis (2012:38) kepuasan adalah tingkat perasaan seseorang setelah membandingkan kinerja produk (atau hasil) yang ia rasakan dengan harapannya.

Dengan adanya tercapainya kepuasan pelanggan yang merupakan tercapainya harapan pelanggan atas barang atau jasa yang digunakan maka akan dapat membentuk loyalitas pelanggan pada barang atau jasa tersebut. Loyalitas pelanggan menurut Oliver (1997) dalam Asmai Ishak dan Zhafiri Luthfi (2011:56) menyatakan bahwa loyalitas adalah suatu kesediaan pelanggan untuk melanjutkan pembelian pada sebuah perusahaan dalam jangka waktu yang panjang dan mempergunakan produk atau pelayanan secara berulang, serta merekomendasikannya kepada teman-teman dan perusahaan lain secara sukarela.

Melihat dari pembahasan di atas, maka dalam melakukan penjualan jasa suatu perusahaan harus memperhatikan kepuasan pelanggan. Kepuasan pelanggan di sini perasaan pelanggan setelah menggunakan 
barang atau jasa yang ditawarkan. Agar kepuasan pelanggan tersebut nantinya berdampak positif bagi perusahaan, maka perusahaan perlu berpikir dengan baik agar kepuasan pelanggan dapat dipertahankan atau ditingkatkan. Diharapkan dengan meningkatkan kepuasan pelanggan maka akan dapat membentuk loyalitas pelanggan.

\section{PENUTUP}

\section{Simpulan}

Dalam penelitian yang berjudul pengaruh kepuasan pelanggan terhadap loyalitas pelanggan pada Obyek Wisata Dumilah Water Park Madiun dapat disimpulkan sebagai berikut:

1. Kepuasan pelanggan pada Obyek Wisata Dumilah Water Park Madiun baik. Hal ini dapat dilihat dari hasil statistik deskriptif bahwa variabel kepuasan pelanggan dengan jumlah 106 orang mempunyai nilai rata-rata 64,77 nilai tengah 65,00 dan angka yang sering muncul 63 dengan standar deviasi 3,994 nilai minimum 54 nilai maksimum 71 dan jumlah 6866 .

2. Loyalitas pelanggan pada Obyek Wisata Dumilah Water Park baik. Hal ini terlihat dari hasil statistik deskriptif di atas bahwa variabel loyalitas pelanggan dengan jumlah 106 orang mempunyai nilai ratarata 62,66 nilai tengah 63,50 dan angka yang sering muncul 64 dengan standar deviasi 4,071 nilai minimum 52 nilai maksimum 75 dan jumlah 6642 .

3. Kepuasan pelanggan mempunyai pengaruh terhadap loyalitas pelanggan pada Obyek Wisata Dumilah Park Madiun. Terbukti dari hasil analisis regresi diperoleh garis regresi $\mathrm{Y}=29,981+0,505 \mathrm{X}$. Artinya apabila kepuasan pelanggan ditingkatkan 1\% maka loyalitas pelanggan akan naik $0,505 \%$, apabila faktor lain dianggap tetap. Dari uji korelasi diperoleh hasil nilai $r_{\text {hitung }}$ adalah 0,495 sedangkan $\mathrm{r}_{\text {tabel }}$ 0,191. Artinya ada hubungan kepuasan pelanggan dengan loyalitas pelanggan pada Obyek Wisata Dumilah Water Park Madiun. Selain itu didukung dengan uji determinasi yang digunakan untuk mengetahui seberapa besar prosentase sumbangan kepuasan pelanggan terhadap loyalitas pelanggan. Diketahui $\mathrm{R}^{2}$ adalah 0,245 . Artinya sumbangan pengaruh kepuasan pelanggan terhadap loyalitas pelanggan yaitu $24,5 \%$ sedangkan sisanya $75,5 \%$ dipengaruhi oleh faktor lain. Sedangkan dari hasil $\mathrm{F}_{\text {hitung }}$ adalah 33,748 sedangkan $F_{\text {tabel }}$ sebesar 3,932, di lain pihak besarnya $\mathrm{Sig}_{\text {hit }}$ adalah 0,000 sedangkan $\operatorname{Sig}_{\text {prob }} 0,05$. Hal ini berarti bahwa nilai $F_{\text {hitung }} \geq F_{\text {tabel }}(33,748 \geq 3,932)$ atau $\operatorname{Sig}_{\text {hit }} \leq$ $\operatorname{Sig}_{\text {prob }}(0,000 \leq 0,005)$, artinya ada pengaruh kepuasan pelanggan terhadap loyalitas pelanggan pada Obyek Wisata Dumilah Water Park Madiun. Sedangkan dari hasil uji $t$ diperoleh nilai $t_{\text {hitung }}$ adalah 5,809 sedangkan $t_{\text {tabel }}$ sebesar 1,660, di lain pihak nilai $\mathrm{Sig}_{\text {hit }}$ adalah 0,000 sedangkan $\operatorname{Sig}_{\text {prob }} 0,05$. Hal ini berarti bahwa nilai $t_{\text {hitung }}$ $\geq t_{\text {tabel }}(22,356 \geq 1,771)$ atau $\operatorname{Sig}_{\text {hit }} \leq \operatorname{Sig}_{\text {prob }}$ $(0,000 \leq 0,05)$, artinya ada beda pengaruh kepuasan pelanggan terhadap loyalitas pelanggan pada Obyek Wisata Dumilah Water Park Madiun. Jadi berdasarkan uji korelasi, uji F dan uji t dapat disimpulkan ada pengaruh Kepuasan Pelanggan terhadap Loyalitas Pelanggan pada Obyek Wisata Dumilah Water Park Madiun. 


\section{Saran}

1. Bagi Perusahaan

Obyek Wisata Dumilah Water Park Madiun sebaiknya dapat mempertahankan kepuasan pelanggan, karena kepuasan pelanggan mempunyai pengaruh terhadap loyalitas pelanggan. kepuasan pelanggan dapat dipertahankan dengan memberikan pelayanan yang terbaik mulai dari harga tiket masuk yang terjangkau dengan memberikan diskon pada akhir pekan atau hari libur, adanya member pengunjung sehingga pelanggan lebih murah dalam masuk ke Dumilah. Fasilitas yang ada harus lebih bervariasi dan menarik dengan menambahkan kolam renang, water boom yang besar, serta kelengkapan permainan air (seluncuran, pancuran air).

2. Bagi Peneliti

Bagi peneliti yang akan datang sebaiknya mengembangkan penelitian dengan menggunakan variabel bebas lain selain kepuasan pelanggan, karena selain kepuasan pelanggan masih banyak faktor yang mempengaruhi loyalitas pelanggan.

3. Bagi Lembaga

Sebaiknya pihak IKIP PGRI Madiun khususnya perpustakaan lebih memperbanyak buku referensi yang berhubungan dengan penelitian, sehingga diharapkan dapat mempermudah pencarian landasan teori dalam setiap penelitian mendatang.

\section{DAFTAR PUSTAKA}

Asmai Ishak dan Zhafiri Luthfi. 2011. Pengaruh Kepuasan dan Kepercayaan Konsumen Terhadap Loyalitas: Studi Tentang Peran Mediasi Switching Costs. Jurnal Siasat Bisnis, Volume 15, No. 1, (http://fecon.uii.ac.id/images/ stories/jurnal/JSB/januari11/7 asmai 20ishak $\% 20 \% 26 \% 20$ zhafiri\%20luthfi $\% 20$-revisi\%20(layout).pdf, Diunduh 4 Januari 2014).

Burhan Bungin. 2005. Metodologi Penelitian Kuantitatif Komunikasi, Ekonomi, dan Kebijakan serta Ilmu-ilmu Sosial Lainnya. Jakarta: Kencana.

Danang Sunyoto. 2013. Dasar Manajemen Pemasaran. Yogyakarta: Caps.

Duwi Priyatno. 2009. SPSS Untuk Analisis Korelasi, Regresi, dan Multivariate. Yogyakarta: Gava Media.

Faisal Matriadi, Teuku Edyansyah dan Saifuddin. 2013. Analisis Faktor-faktor yang Mempengaruhi Loyalitas Pelanggan Pupuk Urea Non Subsidi pada PT. Pupuk Iskandar Muda Propinsi Aceh. Journal Of Ekonomic Manajemen \& Business, Vol. 14, No. 1, ( https://doc-0s-5g-docs. googleusercontent.com/docs/securesc/ ha0ro937gcuc717deffksulhg $5 \mathrm{~h} 7 \mathrm{mbp} 1 /$ Out7ln19kmsjaa0bdedr9s66jrbi9c2g/13 $\underline{94193600000 / 1285165883194553273}$

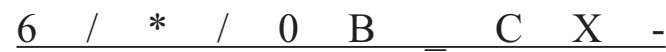
WJOATRxdmNIbDRPaWx2dUU?h=1 $\underline{6653014193614665626 \& \mathrm{e}=\text { download, }}$ Diunduh 20 Februari 2014).

Fandy Tjiptono dan Gregorius Chandra. 2012. Pemasaran Strategik. Yogyakarta: Andi.

Fandy Tjiptono. 2000. Strategi Bisnis Modern. Yogyakarta: Andi.

Malang: Bayumedia.

Gunawan Adisaputro. 2010. Manajemen Pemasaran Analisis untuk Perancangan Strategi Pemasaran. Yogyakarta:YKPN. 
Imam Ghozali. 2012. Aplikasi Analisis Multivariate dengan Program IBM SPSS 20. Semarang: Badan PenerbitUNDIP.

Jonathan Sarwono. 2012. Metode Riset Skripsi : Pendekatan Kuantitatif (Menggunakan Prosedur SPSS). Jakarta: PT. Alex Media Komputindo.

Juliansyah Noor. 2011. Metodologi Penelitian: Skripsi, Tesis, Disertasi, dan Karya Ilmiah. Jakarta: Kencana.

Kasmir dan Jakfar. 2009. Studi Kelayakan Bisnis. Jakarta: Kencana.

Limidi. 2007. Analisis Loyalitas Konsumen dalam Mengkonsumsi Produk Pemutih Wajah (Studi Kasus pada Mahasiswa Fakultas Ekonomi UNISRI Surakarta). Jurnal Ekonomi dan Kewirausahaan, Vol 7, No. 2

(http://download.portalgaruda.org/ article.php?article $=115094 \& \mathrm{val}=5259$, Diunduh 1 Maret 2014).

Mudrajad Kuncoro. 2004. Metode Kuantitatif Teori dan Aplikasi Untuk Bisnis dan Ekonomi. Yogyakarta: AMPYKPN.

Nasution. 2004. Manajemen Jasa Terpadu. Bogor: Ghalia Indonesia.

Ni Nyoman Yuliarmi dan Putu Riyasa. 2007. Analisis Faktor-Faktor Yang Mempengaruhi Kepuasan Pelanggan Terhadap Pelayanan PDAM Kota Denpasar. Buletin Studi Ekonomi, Vol 12 , No. 1 ,

(Http://Teorionline.Files.Wordpress. Com/2010/06/Jurnal-Analisis-FaktorFaktor-Yang-MempengaruhiKepuasan-Pelanggan.Pdf, Diunduh 21 Februari 2014).

Nurullaili dan Andi Wijayanto. 2013. Analisis Faktor-Faktor yang Mempengaruhi
Loyalitas Konsumen Tupperware (Studi pada Konsumen Tupperware di Univer-sitas Diponegoro). Jurnal Administrasi Bisnis, Vol 2, No. 1, (Http://Ejournal.Undip.Ac.Id/ Index.Php/Janis/Article/Download/53 57/4814, Diunduh 16 Februari 2014).

Pandji Anoraga. 2007. Pengantar Bisnis Pengelolaan Bisnis Dalam Era Globalisasi. Jakarta: Rineka Cipta.

Punaji Setyosari. 2010. Metode Penelitian Pendidikan dan Pengembangan. Jakarta: Kencana.

Rambat Lupiyoadi dan A. Hamdani. 2009. Manajemen Pemasaran Jasa. Jakarta: Salemba Empat.

Rambat Lupiyoadi. 2001. Manajemen Pemasaran Jasa Teoi dan Praktik. Jakarta: Salemba Empat.

Rina Rachmawati. 2010. Pengaruh Kepuasan Terhadap Loyalitas Pelanggan (Sebuah Kajian Terhadap Bisnis Makanan). Teknubuga, Vol, No.2, (http://journal.unnes.ac.id/nju/ index.php/teknobuga/article/view/118 2/1122, Diunduh 20 Januari 2014).

Sofyan Yamin dan Heri Kurniawan. 2010. SPSS Complete: Teknik Analisis Statistik Terlengkap dengan Software SPSS. Jakarta: Salemba Infotek.

Sugiyono 2001. Metode Penelitian Bisnis. Bandung: Alfabeta.

2013. Metode Penelitian Pendidikan Pendekatan Kuantitatif, Kualitatif, dan R\&D. Bandung: Alfabeta. 2012. Statistik untuk Penelitian. Bandung: Alfabeta. 
Suharsimi Arikunto. 2010. Prosedur Penelitian Suatu Pendekatan Praktik. Jakarta: Rineka Cipta.

Thamrin Abdullah dan Francis Tantri. 2012. Manajemen Pemasaran. Depok: Rajawali Pers.

Triyono. 2013. Metodologi Penelitian Pendidikan Dilengkapi dengan Contoh
Proposal dan Artikel Untuk Jurnal Ilmiah. Yogyakarta: Ombak.

Ujang Sumarwan. 2011. Perilaku Konsumen Teori dan Penerapannya dalam Pemasaran. Bogor: Ghalia Indonesia.

Zulian Yamit. 2010. Manajemen Kualitas Produkdan Jasa. Yogyakarta: Ekonisia 